\title{
Lactarius hysginoides, a new boreal agaric
}

\author{
MAURI KORHONEN and TAUNO ULVINEN
}

KORHONEN, M. \& ULVINEN, T. 1985: Lactarius hysginoides, a new boreal agaric.
- Karstenia 25: 62-65.

A new milk-cap species, Lactarius hysginoides M. Korhonen \& Ulvinen, is described and illustrated. It resembles $L$. hysginus (Fr.: Fr.) Fr., L. vietus (Fr.: Fr.) Fr., and L. moseri Harmaja, but the taste is mild and the latex remains unchanged, not turning grey. There are also some microscopical differences. The new species is reported from Finland and Sweden. It seems to be widespread in the northern and middle boreal forests, usually growing in mesotrophic, moist, paludified woodland. Probable mycorrhizal partners are Picea abies and Betula.

Mauri Korhonen, Botanical Museum, University of Helsinki, Unioninkatu 44, SF-00170 Helsinki, Finland

Tauno Ulvinen, Botanical Museum, University of Oulu, Linnanmaa, SF-90570 Oulu, Finland

\section{Introduction}

Lactarius hysginoides M. Korhonen \& Ulvinen was tentatively presented in Finnish in the book 'Suomen rouskut' (Korhonen 1984, Finnish name 'nororousku'). The name had been published earlier as L. hysginoides Ulvinen (nom. nudum; Ulvinen et al. 1981) and the fungus had actually been known in Finland for over ten years, mainly in the north of the country, having first been discovered by Tauno Ulvinen. During those first years we gradually learned more about this nameless milk-cap. In particular, several collections and notes on the species were made by Dr. Ilkka Kytövuori. He has kindly placed his fine material and notes at our disposal. It seems that no such species has been recognized earlier in either Europe or North America.

\section{Lactarius hysginoides M. Korhonen \& Ulvinen,}

n. sp. -Figs. 1-2

Lactarius hysginoides Ulvinen, Oulanka Reports 2: 15. 1981, nom. nudum. - Lactarius hysginoides M. Korhonen \& Ulvinen ex Korhonen, Suomen rouskut: 141. 1984, nom. inval.

Illustrations. Korhonen 1984: 140, habit in colour, 216 microscopical details.

Pileus 2-8 cm latus, ex roseo fuscus, aliquantum viscidus. Lamellae albidae, paulum brunnescentes, subdistantes. Stipes validus, admodum brevis, pallide porphyreus, aliquantum viscidus. Latex candidus, immutabilis. Sapor paene mitis. Sporae 7.5-9.5 $\mathrm{mm}$ longae, 5.5-6.5 um latae, fere ellipsoideae, ornamentis fragilibus, minus quam $0.5 \mu \mathrm{m}$ altis. Macrocystidia $45-$ $52 \mu \mathrm{m}$ longa, 5-7 $\mu \mathrm{m}$ lata, gracilia, crassitudine aequa. Habitat in pinetis et betuletis udis.

Holotypus: Finland. Perä-Pohjanmaa: Rovaniemi rural parish, Niskanperä, paludified forest by side of brook Mustonoja NW of Mustonkumpu, moist ground rich in litter, with Picea, Betula, Alnus incana, Salix spp. Grid $27^{\circ}$ E: $7373: 436$, alt. $90 \mathrm{~m}, 21$. VIII. 1979 Tauno Ulvinen (OULU).

Pileus (2-) $3-5(-8) \mathrm{cm}$ wide, becoming shallowly infundibuliform with age, uniformly reddish greybrown to brownish grey, or occasionally with slightly darker brown spots or zones; very rarely with a small umbo; surface somewhat viscid; margin inrolled, rather narrowly pruinose, undulating when older. Lamellae whitish with tinges of yellow-brown and red, subdistant, adnate to shortly decurrent. Stipe pale grey-brown, with a tinge of red, fairly thick and short, often not longer than diameter of the cap, first solid but becoming hollow when old, surface slightly viscid. Context of pileus pale yellow-brown, soft. Latex watery white, unchanging or drying to very pale yellowish grey. Taste mild, but gradually changing to faintly acrid. Spores $7.5-9.5 \times 5.5-6.5 \mu \mathrm{m}$, fairly narrow ellipsoid, ornamentation composed of thin, partly broken or continuous ridges and of isolated warts, mostly not more than $0.5 \mu \mathrm{m}$ high. Macrocystidia $45-52 \times 5-7 \mu \mathrm{m}$, often of equal thickness up to the apex. Pseudocystidia $2-4 \mu \mathrm{m}$ wide. Cap surface hyphae gelatinized, hyaline, with large pigment particles within cells and on their walls when mounted in Melzer's reagent.

\section{Distribution and ecology}

Specimens examined:

Finland. Etelä-Pohjanmaa: Kurikka, Myllykylä, 15.IX.1982 Kytövuori $82373(\mathrm{H})$. Pohjois-Savo: Joroinen, Lahnalahti, 28.VIII.1982 Kytövuori 82164, 82179 (H). Kiuruvesi, Koivujärvi, 18.IX.1982 Kytövuori 82462 (H). Virtasalmi, Ankele, 28.VIII.1982 Kytövuori 82189 (H). Pohjois-Karjala: Pielisjärvi, Matovaara, 16.VIII.1972 Ulvinen (OULU). Keski-Pohjanmaa: Kälviä, between Ruotsalo and Peitso, 16.IX.1982 Kytövuori $82424(\mathrm{H})$; Peitso, 28.VIII.1983 Kytövuori 83092 (H, MICH, O). Pyhäjärvi, Pyhäsalmi, 29.VIII.1972 Ulvinen (OULU). Kainuu: Kuhmo, Juntinsalo, 


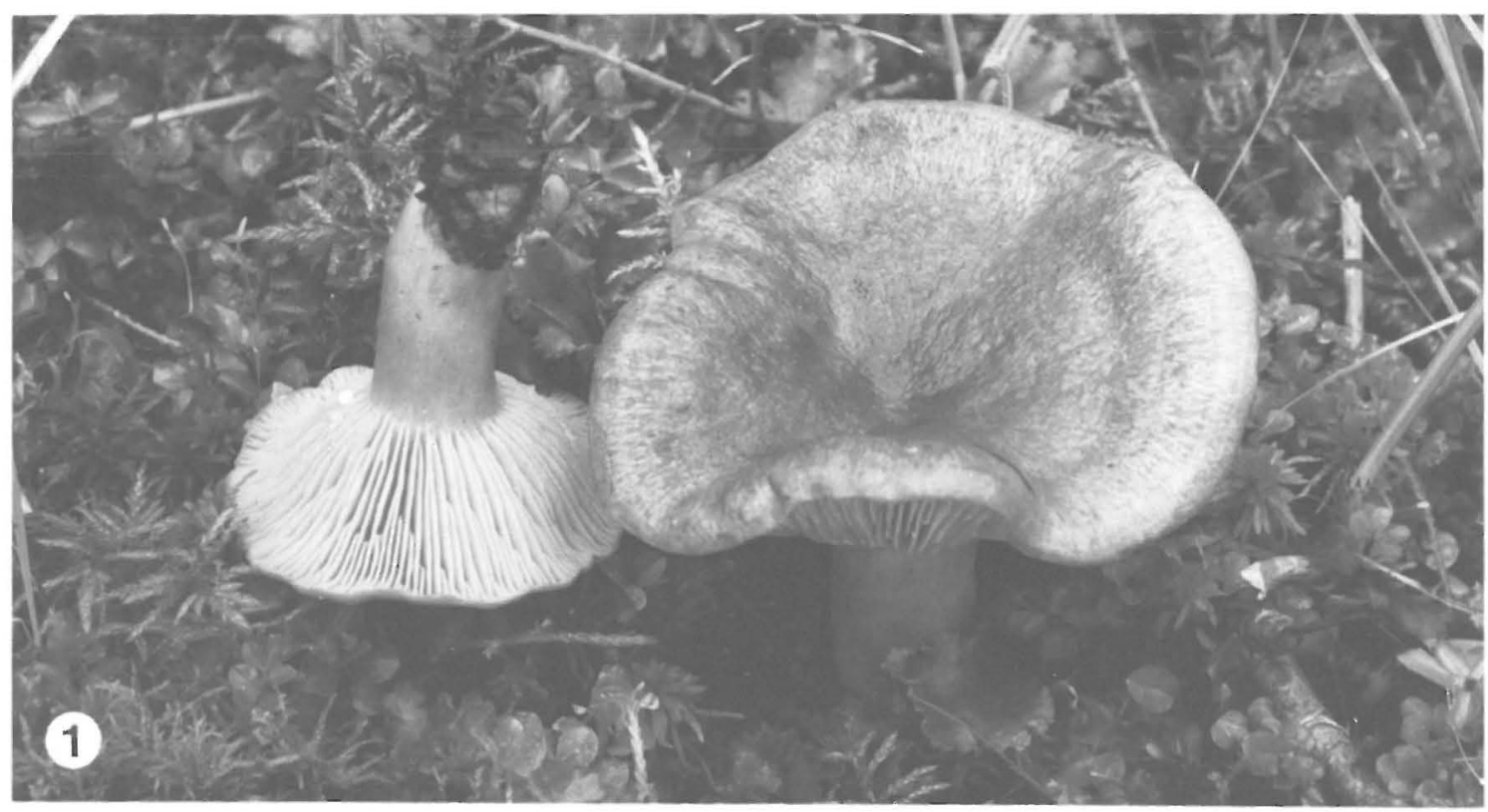

Fig. 1. Lactarius hysginoides. (Sweden, Jämtland, Undersåker, 1983 Korhonen 5437). — Photo M. Korhonen.

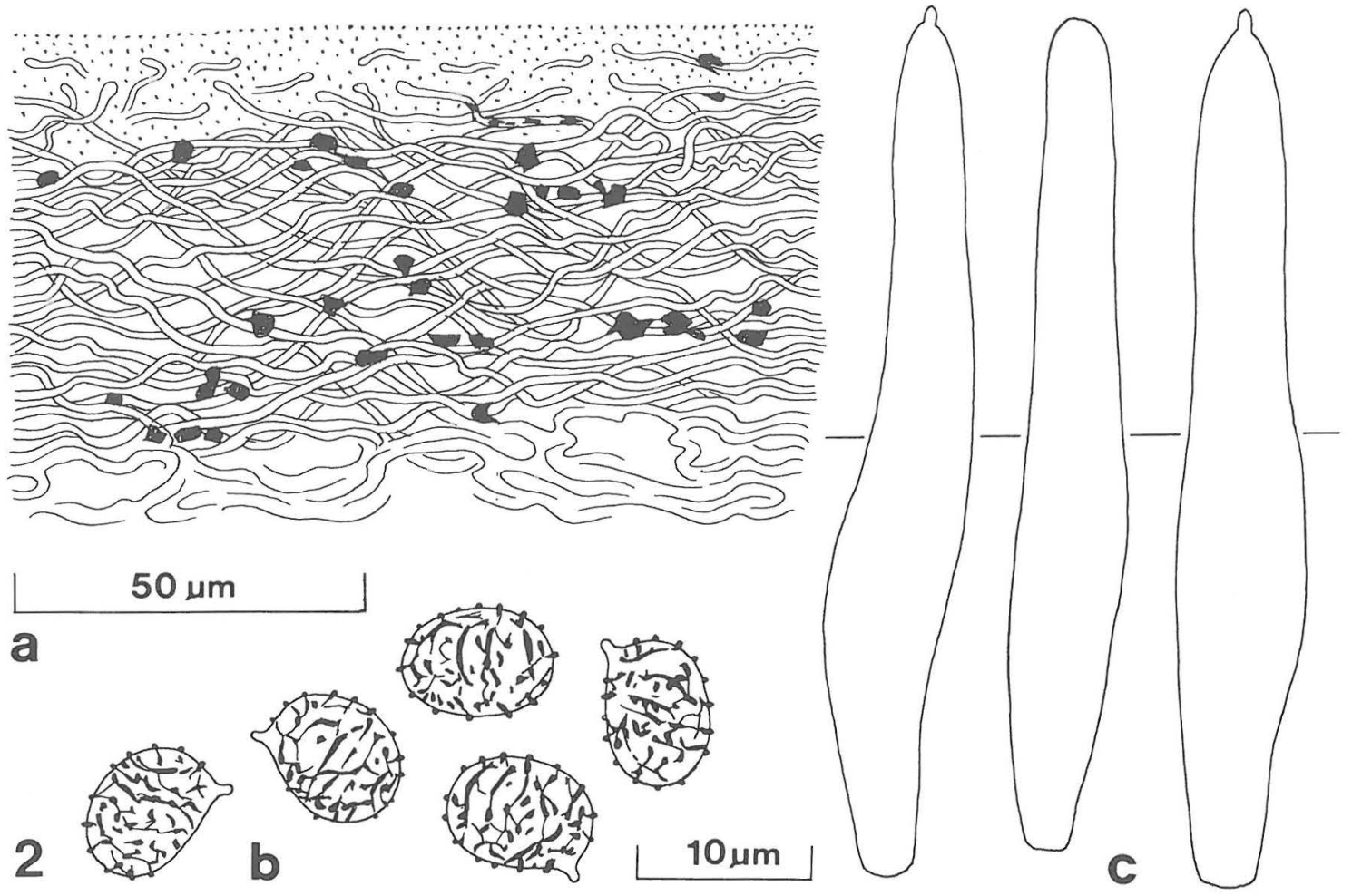

Fig. 2. Microscopical details of Lactarius hysginoides: a) cuticle, $\times 800$, b) spores, $\times 2000$, c) macrocystidia, $\times 2000$. Drawn from the holotype specimen. 


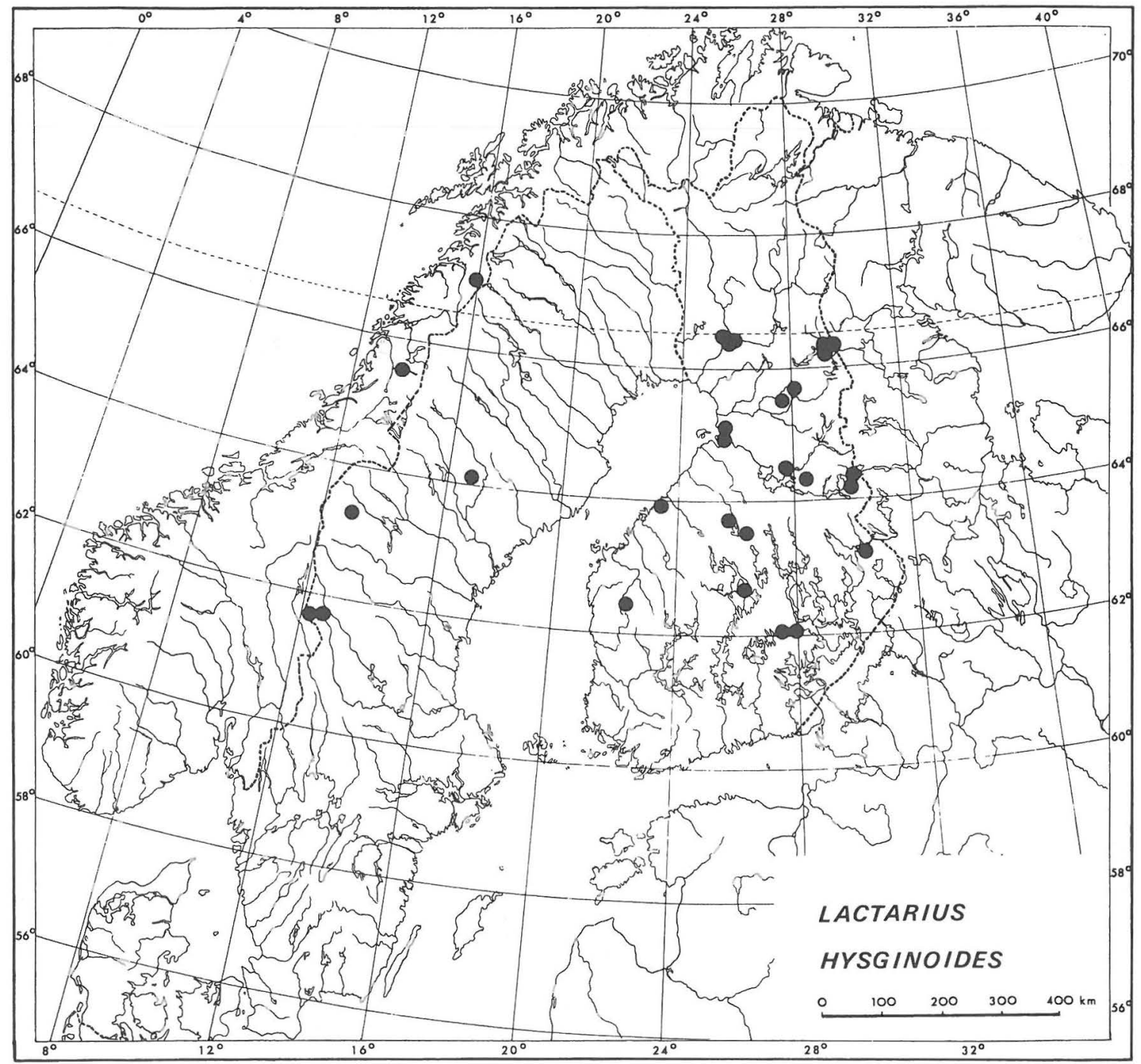

Fig. 3. Distribution of Lactarius hysginoides according to the material examined.

20.VIII.1978 Ohenoja (H, OULU); Lentiira, 3.IX.1980 Kytövuori 80649 (H), 6.IX.1981 Kytövuori 811254 (C, H). Oulun Pohjanmaa: Oulu, Sanginsuu, 12.IX.1969, 19.VIII.1983, 5.IX.1983 Ulvinen (OULU), 25.VIII.1984 Ulvinen (H, OULU); Sanginjoki, 6.IX.1975 Ohenoja (OULU). Pudasjärvi, Kouvanjärvi, 16.VIII.1972 Ulvinen (OULU); Isosyöte, 2.IX.1977 Ulvinen (OULU). PeräPohjanmaa: Rovaniemi rural parish, Pahtaja, 13.VIII.1975 Ohenoja (OULU), 19.VIII.1979 Ulvinen (OULU), 28. VIII. 1984 Ulvinen (H, OULU); between Valajaskoski and Pahtaja, 28.VIII.1984 Ulvinen (OULU); Niskanperä (see type). Koillismaa: Kuusamo, Oulanka National Park, 18.VIII.1976 Ulvinen (OULU); Juuma, 5.IX.1981 Kytövuori 811222 (H, UPS); Liikasenvaara, 19.VIII.1983 Seppänen (H). Sweden. Dalarna: Särna, between Öreån and Bålåsen, 8.VIII.1981 Kytövuori 81385 (H); Gördalen, 9.VIII.1981 Kytövuori $81410(\mathrm{H})$. Jämtland: Undersåker, Välliste,
23.VIII.1983 Korhonen 5437 (H), photograph in Korhonen (1984: 140).

[Addendum Nov. 12, 1985: Finland. Pohjois-Häme: Konnevesi, Aittoniemenkylä, 2.IX.1985 Kytövuori 85004 (H). Kainuu: Paltamo, Kiehimävaara, 9.VIII.1985 Kytövuori $85002(\mathrm{H})$. Perä-Pohjanmaa: Rovaniemi rural parish, Taipale, 8.IX.1985 Kytövuori $85006(\mathrm{H})$. Norway. Nordland: Hattfjelldal, Unkervatnet, 5.IX.1985 Kytövuori $85005(\mathrm{H})$. Saltdal, Balvatnet, 15.VIII.1985 Kytövuori 85003 (H)

Sweden. Asele Lappmark: Asele, Lomsjön, 8.VIII.1985 Kytövuori 85001 (H). - The collection Kytövuori 85003 was made at altitude $590 \mathrm{~m}$, among Salix and Betula, but without Picea, in flooded area of a river bed.]

All collections were made in the northern and middle boreal forest zones (Fig. 3 , see also the map in 
Korhonen 1984: 141), at altitudes of $10-630 \mathrm{~m}$. The collection time is the second half of August and first half of September.

L. hysginoides grows in moist, often paludified forests, along brooks and in the margin of fens, amongst Sphagnum girgensohnii, $S$. russowii, $S$. squarrosum, with mosses of the Mniaceae, such as Rhizomnium magnifolium, Plagiomnium ellipticum and Pseudobryum cinclidioides, and with Hylocomium splendens and needle litter, but also on moist humus and herbaceous and deciduous tree litter with Calliergon cordifolium. It is a species of mesotrophic habitats avoiding the most oligotrophic and perhaps very eutrophic localities, too. The mycorrhizal partners of $L$. hysginoides are Picea abies and probably Betula. Other trees growing in its habitats are Alnus incana and Salix species.

\section{Discussion}

L. hysginoides is separated clearly from other similar, but distinctly acrid Lactarius species by its mild, only faintly acrid taste. As the name 'hysginoides' indicates, the species resembles $L$. hysginus (Fr.: Fr.) Fr. in colour and form, but that species is more copper-brown, firmer-fleshed and mostly larger, having a slimy or viscid cap surface, yellowish and more crowded gills, dark spots on the cap and stipe, and a very acrid taste. L. vietus (Fr.: Fr.) Fr. and $L$. moseri Harmaja (Harmaja 1985) resemble $L$. hysginoides more in habit, but they are acrid and their latex changes clearly from white to grey, while the latex of $L$. hysginoides remains practically unchanged.

The microscopic differences between the species are also fairly clear. The spores of $L$. hysginoides are fairly narrowly ellipsoid and the ornamentation is thin and low, mainly less than $0.5 \mu \mathrm{m}$ high. The spores of $L$. hysginus are small and subglobose with more elevated and robust ornamentation. The spores of $L$. vietus and $L$. moseri are broadly ellipsoid and the ornamentation is up to $1 \mu \mathrm{m}$ high. Many of the cystidia of $L$. hysginoides are uniformly thick up to the top, but those of L. hysginus, L. vietus and L. moseri are more or less pointed.

L. hysginoides is reported to be edible after blanching in boiling water (Korhonen 1984).

Acknowledgements. We are grateful to Prof. Teuvo Ahti for his comments on the manuscript and to Mrs. Anna Damström, M.A., for revising the English text.

\section{References}

Harmaja, H. 1985: Lactarius mammosus and L. moseri n.sp. - Karstenia 25:47-49.

Korhonen, M. 1984: Suomen rouskut. - 223 pp. Helsinki.

Ulvinen, T., Ohenoja, E., Ahti, T. \& Alanko, P. 1981: A checklist of the fungi (incl. lichens) of the Koillismaa (Kuusamo) biological province, N.E. Finland. Oulanka Reports 2: 1-64. 